\title{
Emigrant citizenship, privileged local belonging and the option to return: Germans on the Turkish coast
}

\author{
Margit Fauser(D)
}

\author{
Correspondence: margit.fauser@h- \\ da.de \\ [for the Special Issue "Migration \\ research in the Mediterranean in \\ perspective: variable focal length" \\ Guest editors: Ricard Zapata-Barrero \\ and Luisa Faustini] \\ Department of Social Work, \\ Darmstadt University of Applied \\ Sciences, Adelungstrasse 51, 64283 \\ Darmstadt, Germany
}

\begin{abstract}
The current migratory dynamics in the Mediterranean are characterized by large numbers of displaced people, refugees, and other vulnerable groups. In addition, the Mediterranean attracts more privileged individuals who are migrating for lifestyle reasons to find a better life abroad. But, while political and economic crises are at the roots of many movements across the Mediterranean, the question is whether these are also leading to the "displacement" of the privileged. In addressing this question, the article links privileged lifestyle migration to a perspective on mobile citizenship, focusing on German retirees who have found a new home on the Turkish coast. It builds on various stages of field research, including a recent field trip in May 2018. The article shows how lifestyle migrants engage and entangle emigrant and other sites of citizenship when navigating residential security and when expressing their way of local belonging in times of turmoil, and how their decision to stay in Turkey is paradoxically enabled by their option to return. The article's focus on privileged migration thus also reveals the role of return as a neglected aspect in the study of (emigrant) citizenship.

Keywords: Mediterranean migration, citizenship, privilege, lifestyle migration, crisis, Turkey, Germany, local belonging, return
\end{abstract}

\section{Introduction}

The current migratory dynamics in the Mediterranean are drawing increasing attention to the large numbers of displaced people, refugees, and other vulnerable groups. In addition, the Mediterranean attracts other mobility groups that are much smaller in number, including individuals who are migrating for lifestyle reasons. For several decades, northern European retirees and other lifestyle migrants have been moving to southern Europe (King, Warnes, \& Williams, 2000), and Turkey has become one of the more recent destinations for this type of relocation (Balkır \& Kırkulak, 2009; Südaş \& Mutluer, 2006). According to the Turkish statistics on northern European residence permit holders, property owners, and tourists (Bahar et al., 2009), German citizens represent the largest group and have relocated either temporarily or permanently to the "Turkish Riviera," predominantly in and around the coastal city of Alanya (Südaş \& Mutluer, 2006).

Rather than being a search for political refuge or economic opportunities, lifestyle migration is associated with the cultural practices of those seeking a better quality of life abroad and thus considered the privilege of more affluent individuals (Benson \& O'Reilly, 2009a;

(c) The Author(s). 2020 Open Access This article is distributed under the terms of the Creative Commons Attribution 4.0 International License (http://creativecommons.org/licenses/by/4.0/), which permits unrestricted use, distribution, and reproduction in any medium, provided you give appropriate credit to the original author(s) and the source, provide a link to the Creative Commons license, and indicate if changes were made. 
King et al., 2000). A growing number of researchers now point to the underlying asymmetrical geographies of power, wealth, and postcolonial continuities that enable this type of migration and that shape the privilege of lifestyle migrants (Benson, 2013; Croucher, 2009; Janoschka \& Haas, 2014; Twine \& Gardener, 2013a). A major facilitator in this is the hierarchy of citizenship (Castles, 2005) on the global scale, both in material and symbolic terms, which determines who can be mobile, settle, and stay in a country. But, while the case of lifestyle migrants is different from that of the more vulnerable groups that flee across the Mediterranean Sea from violence, poverty, or unemployment, the question is whether the current crises are also leading to the "displacement" of these privileged migrants.

To address this question, I examine the experiences and responses of German retirement lifestyle migrants who reside on the Turkish coast. Using material collected between 2013 and 2018 I engage with the emergent field of privileged (lifestyle) migration, yet propose a concept of mobile citizenship that focuses on emigrants' citizenship and its entanglements with other sites in the exploration of privilege. This conceptualization of citizenship focuses on the social practices and sense of belonging at various sites that frame how individuals negotiate their mobility and settlement, relocation, staying on, and potential return, particularly in response to the present turmoil. Researchers on citizenship in the Mediterranean are now debating a shift in the value of citizenship from residential security and settlement (the classical perspective) to the opportunities for mobility by means of a European passport (the strategic approach) (e.g. Ahrens, Kelly, \& van Liempt, 2016; Balta \& Altan-Olcay, 2016; Finotelli, La Barbera, \& Echeverría, 2018; Graeber, 2016; Harpaz, 2013; Harpaz \& Mateos, 2019). Here, the case of privileged mobile citizens provides a showcase for how multiple, entangled sites can enable both these values.

First, I will describe some main features of the debate concerning privileged lifestyle migration and then detail my approach to mobile citizenship. After that, I will introduce my case study research and give a brief description of the current crises surrounding the lives of Germans in Turkey. The remaining sections will show how lifestyle migrants engage and entangle emigrant and other sites of citizenship when navigating residential security and when expressing their way of local belonging, and how this behavior plays out in times of turmoil. Finally, I will describe how their decision to stay in Turkey during times of crisis is paradoxically enabled by their option to return.

\section{Lifestyle migration, privilege, and place-belongingness}

"Lifestyle migration" describes the movement of people who are neither fleeing from war and violence nor seeking business opportunities, jobs, or education, but are searching for a "better quality of life" (Benson \& O'Reilly, 2009a). It is seen as "privileged, because it usually does not occur primarily for economic reasons" (Benson \& O'Reilly, 2009b, p. 618; Janoschka \& Haas, 2014, p. 1) - that is, it is undertaken by persons who are more affluent and better off (Benson \& O'Reilly, 2009b; King et al., 2000), who are "going first class" (Amit, 2007).

More recently, scholars have paid more attention to lifestyle migrants' privilege as a characteristic of citizens from highly industrialized countries in the Global North who move to southern countries and increasingly to the Global South, where wealth and power differentials shape their privilege in relational terms (Benson, 2013; Croucher, 2009; Hayes, 2015; Janoschka \& Haas, 2014; Lundström, 2014). This scholarship has started to engage with postcolonial legacies to reveal the continuing and renewed impact of structural and symbolic asymmetries that shape the images and imaginations of places, as well as the resources, subjectivities, and experiences of people, on which the privileged can capitalize. 
In the debate about privileged migration, surprisingly little attention has been paid to the role of citizenship. Although references have sometimes been made to citizenship status, they are generally made in passing, without engaging further with either the concept or the reality of citizenship itself. Yet the global hierarchy of citizenship and its attached resources (Castles, 2005) are part of and further shape the unequal geographies of power and the status of individuals. In this vein, citizenship greatly contributes to what I consider "spatial privilege" - that is, the capacity to move, to relocate and stay, or to return, or to remain immobile (Fauser, 2020), and thus to use the differential resources of citizenship that are available to some but not to others (Kofman, 1995).

Lifestyle migrations are therefore one example of the "geographies of privilege" (Twine \& Gardener, 2013b) - that is, the ways in which social inequalities are mapped onto, constituted in, and reproduced in space, within the local neighbourhood as much as through global mobility. Privilege sheds light on the neglected, invisible, and frequently normalized site of social inequalities, in individual experiences as well as in academic research (McIntosh, 2010 [1989]; Twine \& Gardener, 2013b). It reflects the hierarchical categorizations of class, race, gender, age, and (not least) citizenship, and of space, including the complicated intersections that can result in additive or ambivalent and sometimes contradictory locations (Anthias, 2012; Lundström, 2014). Thus, citizenship can help make sense of the hardships some lifestyle migrants face abroad (Green, 2014) that have been overshadowed by a focus limited to class privilege. Specifically, the participants in my study, as well as those in a growing share of studies (Ahmed, 2015; Benson \& O'Reilly, 2018), qualify as "ordinary" middle- and lowermiddle-class individuals who still realize their spatial privilege.

These migrants' aspirations for a better lifestyle tend to be associated with a desire for an authentic experience of natural landscapes and local cultures, whether the local "Mediterranean way of life" (Rodríguez, Fernández-Mayoralas, \& Rojo, 1998) or "Turkish hospitality" (Südaş \& Mutluer, 2006), and a life spent in separate residences, often with minimal close social interaction with locals. This has led to an assessment of weak territorial attachment shaped by the "illusion of being at home" (Huber \& O'Reilly, 2004, p. 348), a "home' [that] is not spatially confined to a particular place" (McWatters, 2009, p. 157). When faced with deteriorating conditions of personal health or external circumstances, these "landscape nomads" move back home or further on (King et al., 2000; McWatters, 2009).

However, newer studies among recent lifestyle residents highlight a sense of local belonging and place attachment and the elective nature of such behavior (Benson, 2016; Gustafson, 2001; Kordel \& Weidinger, 2019; van Noorloos, 2013). In fact, the results of both quantitative surveys and qualitative field research document the predominance of these migrants' intentions to stay (Kordel \& Weidinger, 2019). This scholarship also stresses the simultaneous presence of migrants' transnational ties and continued mobility to their places of origin (Gustafson, 2001; Kordel \& Weidinger, 2019). A key aim of this article is to show how social practices and individuals' experiences and claims to a community and place both build on and interconnect local and emigrant sites and how these factors are shaping the processes of staying and of returning in normal and crises times.

\section{Conceptualizing mobile citizenship}

To address these questions and thus contribute to the understanding of a particular, privileged form of Mediterranean migrations, I suggest a concept for mobile citizenship that engages with its varied dimensions and the locations that mobile citizens criss-cross and entangle. 
Although citizenship encompasses more than just its classical legal definition, it is still foremost considered a legal status coupled with rights; as such, especially in the context of migration, citizenship is decisive for marginality or privilege by including some and not others, or some only to certain degrees (Castles, 2005; Kofman, 1995). Even though the legal dimension is crucial, feminist, anti-racist, and other critical scholars have long called for citizenship to be considered a social practice as well, with a recognition of how daily life and claims are shaped by laws and may reach beyond or contradict the law (Staeheli et al., 2012). Engin Isin's (2008) notion of "acts of citizenship" and Lynn Staeheli and coauthors' (2012) conceptualization of "ordinary citizenship" have recently provided new pathways for empirical research on this dimension. Lastly, citizenship is reflected in the emotional dimension of affective belonging to a community (Bosniak, 2006).

Thus, there is no linear relationship among the legal, social, and affective dimensions, as exemplified by claimants without rights, denizens without status, and naturalized migrants and cultural and racialized minority citizens who resist denied belonging. Staeheli et al. (2012) offer a helpful viewpoint on "ordinary citizenship" that sheds light on the ways in which "law and ordering are normalized through daily life" and on how individuals draw on "a range of resources and claims beyond the law" to negotiate their position and articulate their belonging (p. 640). Whereas these authors, like many other scholars in migration studies, are concerned with those citizens who negotiate their marginalization and exclusion, other citizens negotiate a much more privileged position, which is likely to succumb to even greater normalization. The citizenship of mobile citizens is also not confined to one state space, and their practices are oriented and can draw together multiple spaces of law and ordering and of affective belonging.

In the debate on multiple citizenship, transnational scholars have pointed to the simultaneous involvement with two countries (Faist, Fauser, \& Reisenauer, 2013). In this debate, Nina Glick Schiller and Peggy Levitt (2004) distinguish "ways of being" - the practices and social relations in which individuals engage - from "ways of belonging," which refer to affective identification. Others have added more complicated spatialities, the role of postnational spaces, and the role of the city, place of residence, and local community as a space for citizenship (Staeheli, 2003). As citizens of multiple spaces, mobile individuals can give different meanings to and negotiate and express different dimensions of citizenship vis-à-vis different sites.

For example, a growing number of studies reveal the flexible and strategic approaches on the part of naturalized citizens in the Mediterranean region and elsewhere. This attempt to overcome political and economic insecurities and maximize opportunities (Bauböck, 2018; Harpaz \& Mateos, 2019) has been observed among refugees and labour migrants in crisis-affected countries such as Spain and Italy who seek formal citizenship in their quest to move on within the EU (Finotelli et al., 2018). It has also been found among Israelis who use new dual-citizenship opportunities not to emigrate but to "create options," not least the option to be mobile (Harpaz, 2013; Leuchter, 2014), and among Turkish citizens who arrange to acquire US birthright for their children (Balta \& AltanOlcay, 2016). This category of flexible citizens thus evaluates citizenship based on the access it provides to strategic options, notably spatial mobility, business opportunities, educational prospects, or prestige, yet is devoid of territorial identities and belonging. Their approaches are calling into question the connection between citizenship and the wish to 
stay and to belong (Finotelli et al., 2018; Harpaz \& Mateos, 2019; Leuchter, 2014; Ong, 1999). In the same vein, early transnational scholarship had observed a deterritorialization of identities and thus their decoupling from rights and status (Appadurai, 1998; Leitner \& Ehrkamp, 2006). Some of the literature on privileged lifestyle migration considers its subjects as a prototype of such deterritorialized affiliations as well.

Yet geographers in particular have contended that territory-transcending and multiple citizenships do not necessarily negate the role of territory. In line with parts of the lifestyle migration debate addressed above, they consider that belonging still often ties individuals to territorially defined polities at the sites of immigration or emigration. This relationship is becoming increasingly complex, while the local scale is often particularly relevant to everyday experiences of citizenship and belonging (Leitner \& Ehrkamp, 2006; Staeheli, 2003). Rather than reifying the binary conceptualizations of national-local or origin-destination, citizenship needs to be seen as organized across multiple spatial scales. Yet the spatially diverse legal, social, and emotional dimensions of citizenship cannot be viewed as simply existing in parallel; rather, they must be seen as being interrelated and together influencing mobile individuals' experiences, choices, and agency-making for their entanglements (Faist, 2001; Isin, 2008). Some transnational scholars in spatial and urban studies have pointed to convoluted interconnections of status, rights, practices, and belonging that cut across and connect various local, national (immigrant), and transnational (emigrant) sites (Staeheli, 2003) (Desforges, Jones, \& Woods, 2005; Ehrkamp \& Leitner, 2003). Others have argued that cross-border practices and belonging often build on local identifications (Guarnizo \& Smith, 1999). This article will show that the reverse is also true: For German retirement lifestyle migrants in Alanya, it is their emigrant citizenship that greatly facilitates their "spatial privilege" to move and relocate abroad and to develop a sense of (privileged) local belonging while maintaining their option to return. This latter option, in turn, further undergirds the experiences and practices that allow German citizens to stay in Turkey in times of insecurity, when so many other groups are displaced. Although these can be conscious acts, more often than not they reflect the normalized experiences of mobile citizens, invisibly shaped by order and law, that come to the fore with privileged migration.

\section{Germans on the Turkish coast}

This article builds on a study of German citizens in the Turkish city of Alanya, located on the Mediterranean coast. Since the 1990s Alanya has developed as a tourist destination and subsequently into a place for European residents (Balkır \& Kırkulak, 2009). With a population of 300,000 in the larger area, it hosts between 2 and 3 million tourists every year, as well as an estimated 15,000 Europeans (www.alanya.bel.tr, accessed 11 November 2013). This figure includes several thousand Germans who rent or own property and live there permanently or temporarily, yet the actual number is unknown. ${ }^{1}$ My study concentrates on the majority of German retirees but includes a few of those who are married to Turkish citizens or who have set up a business. In addition, former Turkish "guest

\footnotetext{
${ }^{1}$ According to statistics from the local police department in Alanya, almost 5000 residence permits were issued to German citizens between 1994 and 2013. However, it is unclear how many renewals are included in this number and how many permits are currently valid. National statistics reveal that out of an estimated 90,000 to 120,000 Germans in the country, only about 10,000 hold a Turkish residence permit (Bahar et al., 2009; İçduygu \& Sert, 2009).
} 
workers" and their German-born children have relocated to Alanya (Nudrali \& O'Reilly, 2009; Südaş \& Mutluer, 2006).

Lower living costs and warmer climates generally motivate the relocation of Germans for whom Alanya is seen to be a particularly welcoming place. Because of returned migrants and a flourishing tourism industry, many local officials, shopkeepers, and neighbours speak German, which helps to alleviate linguistic challenges confronted in a foreign country. Moreover, local authorities have favourably responded to and promoted the investments and settlements of Europeans, following a generally multicultural agenda (Unutulmaz, 2006; Fauser, 2020). The city offers a cemetery for non-Muslims, the Alanya Yabanclar Mezarliği (Alanya Foreigners' Cemetery), and a municipal foreigners' committee that represents the diverse foreign resident communities, facilitates information exchange, and organizes cultural events such as an annual Christmas market. A German-Turkish association and a German ecumenical Christian association that unite two branches in Alanya and Antalya are also important elements in the local life of the German community.

The data I draw on were collected during three stages of field research, each of which lasted between 2 and 6 weeks, undertaken in 2013 and 2014 and through a revisit in 2018, which allowed me to observe continuities and changes in the context of the conflictive and controversial political and geopolitical situation in Turkey and that country's relationship with Germany. The study comprises narrative in-depth interviews with about 20 individuals, including repeated interviewing across the three field trips. Interviewees were purposefully selected based on their living in Alanya (almost) the entire year and therefore holding a residence permit (ikamet), unlike many studies on lifestyle (retirement migration) that account for many shorter stays. Several of the interviewees regularly stayed in Germany for one or two months, some visited their families for a week once or twice a year, and others had not been to Germany at all in the past years. The socio-economic profile classified my interlocutors as members of the middle- and lower-middle classes in terms of education, (former) occupation, and income level. Following a reconstructive, qualitative grounded theory approach, the interviews focused on how migrants were negotiating their everyday lives and political and social citizenship in relation to multiple sites and spaces. These data were subsequently transcribed and coded with Atlas.ti to reveal the practices and perspectives articulated by my respondents and to determine how law and institutions may be ordering their lives. These interviews were embedded in a wider ethnography, using participant observation during events, gatherings, and numerous occasional and informal conversations at meetings, lunches, and shared day trips; analysis of documents and internet blogs from the German community; and the results of eight expert interviews with key informants from the German community and local authorities to help better understand the legal and institutional contexts.

Between my first and last field trips, Turkey had experienced a variety of economic and political crises that also concerned its relationship with Germany. Among the major disruptive events were the violent repression of the Gezi Park protests of 2013; the resurfaced Kurdish conflict since 2015; the killing of eight German tourists in Istanbul's historic center through a suicide attack related to ISIL in early 2016; and the attempted coup d'état in July 2016, together with political reforms, a new constitution, and the installation of a presidential system in 2017. These events were accompanied by the arrests, dismissal, and prosecution of tens of thousands of Turkish citizens. Detained in Turkey were also several German and German-Turkish journalists and human rights activists, while 
others were being stopped or denied entry at the Turkish borders. Germany has granted asylum to some of those who fled from Turkey. Turkish politicians have been barred from campaigning in Germany among their extraterritorial voters. In 2017, the German Foreign Office revised its travel information on Turkey twice, warning that false arrests were possible even in tourist regions and that consular aid was not always allowed access. Turkish state officials responded by warning Turkish citizens against traveling to Germany because of possible racist incidents and verbal attacks there. In 2016, the growing numbers of refugees moving across the region and toward Europe gave way to the EU-Turkey deal, severely criticized by international refugee and human rights organizations for its failure to recognize refugees' needs and rights. The liberalization of visa restrictions for Turkish citizens has not yet taken effect as promised. As early as 2016, between 2000 and 3000 Germans left Turkey (Deutsche Welle, 2016), and the number of tourists had decreased as well. German media frequently reported on Turkey's "tourism crisis" and what some commentators have called "life in the dictatorship" (ZDF, 2016).

\section{Residential security}

Whether in times of crisis or in normal times, the acquisition of formal citizenship is the most reliable mechanism when navigating residential security (Finotelli et al., 2018; Graeber, 2016; Leitner \& Ehrkamp, 2006). Nira Yuval-Davis (1991) considers the "spatial right" to enter and remain in a country to be the most basic citizenship right, and Marco Antonsich (2010) argues that the emotional sense of belonging, feeling safe, and being at home and at ease is shaped to a significant degree by the prospect of being able to stay in one place. The notion of "strategic citizenship" has contrasted these notions with the opportunity to be mobile (Harpaz \& Mateos, 2019). Yet mobile individuals negotiate their (privileged) citizenship, the legal frameworks and social practices, and senses of belonging in relation to multiple sites that together enable both spatial mobility and residential security.

Formal citizenship acquisition has not been on the agenda of researchers who study lifestyle migrants, but one of the key themes is whether or not these migrants register at their place of residence to become formal local citizens with rights and obligations. Studies have documented that part of this group is too mobile, resembling (long-term) tourists, while another part avoids the registration obligations for reasons of taxation, access to welfare rights in their country of origin, and other bureaucratic hurdles; still others do register, and some also become politically involved (Coldron \& Ackers, 2007; Kordel \& Weidinger, 2019). These flexible, and sometimes abused, strategies (Coldron \& Ackers, 2007) show how legal provisions are interpreted and handled within a comparatively ample frame, documenting how "a relatively privileged status results in agency" (Kordel \& Weidinger, 2019, p. 8). In this context, the free-movement rights of European citizens are largely taken for granted and normalized in daily life (Ferbrache \& Yarwood, 2015). Outside the EU, the case of Germans in Alanya exemplifies the role of emigrant citizenship in facilitating territorial entry and local residence in another country, its recognition and facilitation from the immigration site and locality, and how this too is a normalized experience.

Many Germans in Turkey use visa-free entry, which allows them stays of up to 90 days an option still not available to Turkish citizens intent on entering Germany - and they spend longer periods on the Turkish coast before they return to Germany for several months and then travel back to Turkey. Because my sampling frame was focused on permanent residents, 
all the respondents with whom I conducted in-depth interviews held a residence permit (ika$m e t$ ). Acquiring Turkish citizenship is quite difficult, and dual citizenship in Germany is subject to a number of restrictions. Since 2014, permanent residence permits have been available to those who can prove uninterrupted residence in Turkey for a minimum of 8 years. Before that, permits were granted for 1, 2, or 5 years. Nevertheless, my interviewees reported that they were able to extend and make permanent their stays in Turkey with few restrictions. As in most countries, residential permission is conditional on the applicant's regular income or savings. Turkish Directorate General of Migration Management explicitly mentions that a pension certificate can proof such an income (https://e-ikamet.goc.gov.tr, accessed 8 November 2017). Thus, German senior citizens who have formally retired because of old age, redundancy, or health issues and who receive a monthly income from the German statuary pension scheme are able to meet the self-sufficiency requirements in Turkey. Within this framework, the interviewees stated that, although it is a relatively bureaucratic procedure, obtaining

a residence permit is not a problem for a European (...) if you can prove either that for every month that you want the permit you have \$500 US in a Turkish bank account ... or that you are a pensioner and you receive a pension regularly. (Hans, ${ }^{2}$ interviewed 2013 in Alanya).

We have a permit, for 5 years - that's the longest term you can get at the moment. But this is absolutely no problem; you just have to renew it every 5 years. (Wolfgang, interviewed 2013 in Alanya).

Now, I have never heard of anyone who had real problems in receiving a residence permit. (Renate, interviewed 2013 in Alanya).

Moreover, in the past, requesting a permit mandated a trip to Antalya, but this requirement has been facilitated by the installation of a local office, which had originally been housed at the police department but is now at the migration office. This administrative relocation is the result of successful intervention by a local German-Turkish association, as well as mediation by the municipality, and is indicative not only of the bottom-up strategies employed by local foreign residents to advance their local situation but also of the favourable responses by public authorities, especially the local agencies.

Hence, being admitted to Turkey and allowed to remain there is experienced as an uncontested condition. Although the legal frameworks and social practices engaged in by Germans in Alanya involve multiple sites of citizenship, these migrants' choices are usually not articulated in terms of citizenship but through a sense of entitlement that distinguishes them from other migrants.

The resident does not want anything from Turkey other than his residential permit.

(...) He brings money for his maintenance. (...) The resident wants, unlike the labour migrant or the asylum seeker, nothing from Turkey; on the contrary, he is bringing something that Turkey urgently needs: money.

This perspective, formulated in an internet blog discussion maintained among Germans in Alanya, was shared in conversations and interviews as part of my case study. In fact,

${ }^{2}$ The names of all the interview subjects have been changed. 
the interviewees rarely considered themselves to be migrants, which is similar to the selfdistinction found in comparable research (Croucher, 2009; Janoschka \& Haas, 2014). More importantly, this distinction informs their claim to stay and to be treated accordingly, whereas the skills, labour, and taxes contributed by other migrants seem less worthy. Drawing on their emigrant citizenship status and social entitlements for a better life in another country is largely taken for granted by these lifestyle migrants.

\section{The privileged belonging of foreign residents in times of turmoil}

While counting on residential security, lifestyle migrants are often said to display deterritorialized identities, being weakly attached to and scarcely integrated into the community where they reside (Huber \& O'Reilly, 2004; King, 2000). In contrast, more recent research stresses their local belonging as welcomed foreigners who feel that " $\mathrm{t}]$ hey love us here," as cited by Sheila Croucher in her study of US Americans in Mexico, and this feeling is accompanied by varying degrees of comfort with or awareness of their privileged status (Benson, 2013; Croucher, 2009; Hayes, 2015). Similarly, my respondents expressed a mode of belonging as welcomed local foreign residents. This mode both becomes more pronounced in and shields against current turmoil.

All the respondents expressed a sense of being at home and of belonging when they talked about their chosen residence. Angelika, like many of the others, stressed that "we do have a feeling of Heimat (home) here." In their narratives the German retirees in Alanya emphasized that they are leading active lives with many meaningful social relationships, often with other Germans and, to a degree, with the local population. Although the majority of the retirees spoke little Turkish, this language barrier did not prevent social contact with members of the local (Turkish) population or a sense of feeling at home - a finding supported by survey data from the region (Bahar et al., 2009). Many local Turks speak German or English, which is very useful in everyday communications not only with official institutions and services but with neighbours, according to many narratives. My respondents also stressed what a comfort it was to have affectionate social relations that relied on only basic language skills and that they attributed to the culture of Turkish hospitality as an everyday experience. However, these relationships were usually distinguished from deep friendships, which, according to the interviewees, are difficult to establish because of the limited language skills and cultural and religious barriers. Taken together, however, all these factors lead to a sense of rootedness.

In fact, many, like myself, feel rooted here now. (...) You need to have social contacts. In Germany, too, but especially abroad, otherwise you grow lonely, right? And in this sense, I feel very rooted here now. (Renate, interviewed 2013 in Alanya).

A good example of such rootedness is the case of Monika and Klaus, who live in a small village in the outskirts of Alanya. There are many Turkish families living in their village, both younger and older couples with children and grandchildren, including a few young German women who are married to Turkish citizens. Although Monika and Klaus know very little Turkish, they speak highly of their neighbourhood relations, as well as of other social contacts outside the village, shared mainly with other Germans. They are also feeling increasingly distant from political and social affairs in Germany while not identifying as Turkish either: 
In our village, where they know us, where we also somehow belong, but we would never say that we are Turkish or so, we are still guests, and we are being treated like guests, and being treated like guests is a preferential treatment.

When they expressed their sense of local belonging and of being at home, the German respondents in Alanya did so with reference to their special status as guests or foreigners and often as European, yet as residents. Many of the narratives emphasized that belonging relates to a particular place, its physical qualities and landscape, the local population's culture and hospitality, and the Germans' social ties with Turkish locals. This is experienced as part of a generally hospitable local cultural environment in which a German's material and symbolic resources are particularly highly regarded. However, more meaningful friendships and an active social life are predominantly found in the company of other Germans. At the same time, the foreigners' local belonging is far from becoming Turkish, both in terms of formal status and national identification.

This sense of belonging as privileged foreign local residents further translates into a tendency to refrain from political involvement and comments. In 2013, when I asked my interviewees whether they would want to vote in local elections, few said they would. A similar result was found in a survey where only $25 \%$ of the German respondents in Alanya reported an interest in voting in the local elections (Balkır \& Südaş, 2014). My interviewees explained that their reluctance to vote was due to their poor language skills and their limited knowledge of domestic and local dynamics and political traditions. Their general view was that foreigners should stay out of Turkish affairs. Several of the interviews conducted 5 years later showed that this position had become more pronounced.

On the one hand, feeling welcome as a foreign resident is reflected in the emphasis on the experience "that we as foreigners are not affected" by domestic political tensions or international conflict. In 2018, all my respondents stated that "nothing has changed for us" and that there was no need to return to Germany in response to external circumstances. On the other hand, many had become more cautious about expressing their political opinions. In order not to raise suspicion among their neighbours and other locals, some even did not dare to mention Turkish President Erdoğan's name when talking in public, not even on their private balconies; instead, they referred to him by a randomly chosen German surname. The fact that this practice is commented on in blogs indicates that it is a fairly widespread strategy, although several of the comments show that other Germans consider this practice ridiculous and unnecessary because freedom of speech exists in Turkey too. This is a good example of the divergent views with respect to how foreign residents conceive of the political tensions and their consequences for their own lives. However, there is general agreement that Turkish politics is an internal affair in which foreigners should not intervene, even if they are permanent residents with no intention to leave.

On the contrary, all my respondents said they felt safe and protected, not least because of the local authorities' efforts. One example is the fact that the Saint Nicholas community is now protected by police during religious services and meetings, which is not regarded as a reflection of insecurity or threat, but as a sign that the local authorities are being watchful and are willing to protect the community. In an interview with the Catholic radio station Domradio, the priest of the Antalya branch expressed 
reasoning similar to that of other Germans in Alanya. When asked about the life of a Christian community in an Islamic country, the priest said:

When our community was founded 12 years ago, those who wanted to found the community received support from Ankara, to be granted legal status. It was not the legal status of a religious minority, but at least an association according to Turkish law was founded with the name Saint Nicholas Church (...). This allows us to practise our Christian faith without interference. (...) We also realize that the local authorities attach importance to a dignified burial of Christians. And since March [2016], the Christian community has been receiving police protection for all its ceremonies without request. This is the case all over the country. Our people of Saint Nicholas appreciate this very much and find it comforting. In sum, we do not face any obstacles (Domradio, 2016).

In the same vein, the interviewees in Alanya stated that they actually felt particularly welcome, given the continued support in times of crisis. In this situation, their condition again contrasts with that of other migrants, notably with that of the many Syrian refugees being hosted in Turkey. On at least one occasion, when a boat bearing a group of refugees from Syria arrived on Alanya's coast, the 154 passengers were given food and drink, after which a bus took them to other Turkish provinces outside the tourist areas. Many of my respondents had heard about this treatment, but none of the people I spoke with said they found it strange. The reason given by everyone who commented on the country's response to the arrivals was that the refugees were poor and might beg for money, thus disturbing the tourists. Through this narrative, the retirement lifestyle migrants implicitly reinforced the notion that their particular status as welcomed foreign residents differed greatly from that of other (migrant) groups. Hence, their claim of local belonging operates within the confines of foreign residents and sets them apart from Turkish citizens and also from refugees and labour migrants who have fewer material and symbolic privileges.

\section{Safeguarding the option to return}

Local belonging is also documented in studies showing the predominance of emigrants' intention to stay. For instance, a study among Germans on the Spanish island of Mallorca found that $78 \%$ of the respondents wished to remain there (Kaiser, 2011, p. 278). Other data reveal somewhat lower inclinations among Germans in Spain, depending on whether they lived abroad temporarily or more permanently (Kordel \& Weidinger, 2019 , p. 8). Scenarios of return have made reference to enhanced care needs, inadequate or inaccessible care services, and decreasing well-being abroad; a drastic drop in exchange rates; and overdevelopment (Hardill, Spradberry, Arnold-Boakes \& Marrugat, 2005; McWatters, 2009). Few researchers have investigated the negotiations regarding the options to stay or to return. Hardill and her coauthors (2005) are among the few who have documented how British seniors stay on in Spain in spite of health and financial strains. So far, political insecurities and economic crises have not been considered.

Hence, similar to what other studies have reported, my respondents stressed that they wanted to stay, although even in 2013 they had noted that at some point their health situation and the economic and political instabilities in Turkey might make it necessary for 
them to return to Germany. In my interviews and in many more informal conversations, the country's increasing Islamization and nationalization were recurrent topics. Still, on revisiting Alanya in 2018, I met many of those I had spoken with 5 years earlier; the rest had either died or had left because appropriate solutions to their deteriorating health were not available where they lived in Turkey. Paradoxically, however, the local place attachment of those who stayed was facilitated by their emigrant citizenship both in legal terms and in their social practices, whereas only one of my interviewees made mention of state citizenship. Rather, their residential strategies for keeping or arranging for a home back in Germany indicated that Germans in Alanya keep their option to return open. Citizens' right to return to their country of citizenship, by contrast, is part of the everyday normalization of citizenship (Staeheli et al., 2012) and the unacknowledged privilege (McIntosh, 2010 [1989]; Twine \& Gardener, 2013b) of mobile individuals.

About half my sample of German citizens in Alanya still had an official address in Germany, and most of them also still had an apartment there. Others had sold their house or given up their apartment in Germany in exchange for one in Alanya. Surprisingly, some of those who had done so eventually began renting or buying an apartment in Germany again several years after their relocation to Alanya. For example, during our long conversation, Peter stated that he and his partner had bought their apartment in Alanya after carefully preparing for their relocation abroad and visiting several Mediterranean countries. They had chosen Alanya because of the housing prices and infrastructure and the existing health care facilities, and because they had liked the city during their stays. Peter told me that he wished to be buried in Alanya and had in fact already made the necessary preparations; however, he was also afraid that it might not be possible to deal with any complications resulting from deteriorating health in his preferred place of living, especially if he should need long-term treatment. Much later in the conversation, Peter stated that several years after relocating to Alanya, he and his partner had secured an affordable apartment in a housing cooperative (Wohnungsbaugenossenschaft) in Germany. This decision was based on the increasing Islamization of Turkish politics, which seemed to make it necessary to have an exit option. In a recent blog comment, a woman who had just settled in Alanya reported a similar strategy, telling her readers that looking for a place to rent in Germany now was a wise decision for her and her family, which "considering the many problems in Turkey [is] perhaps the better way."

These examples show that although these migrants usually plan to stay abroad, they also develop strategies that might facilitate their eventual return. Many of my respondents kept an official address for administrative purposes and to avoid problems with their pension fund and health insurance, often in response to the bureaucratic hurdles they encountered as emigrant citizens when dealing with German institutions. Some had kept the apartments they rented or owned in Germany so they could visit family and friends or spend time in Germany during the hot Turkish summers. Peter and others had secured a place only a few years after moving abroad. Having a German address and home was regarded as a safeguard to protect themselves against potential risks - "you never know" being an oft-heard explanation.

Jutta and Dieter, whom I interviewed in May 2018, told me how much they enjoyed their spacious apartment in Alanya, which they had bought some years earlier. They also told me that they had no reason to leave Alanya despite the fact that they were critical of the political situation in the country. They had sold their house and car in Germany, 
rented a container to store some of their belongings, and brought with them to Turkey only the most important appliances for everyday use and some keepsakes. Over the past 5 years, they had stayed with close friends during their visits to Germany, where their children and other family live, but they no longer wanted to inconvenience them. Shortly before our conversation, they had started renting an apartment in Germany. Reflecting on the recent political events, the couple told me that they had in fact considered selling the apartment in Alanya, but they repeatedly stressed that this did not mean they wished to return. Instead, their plan was to rent an apartment in Alanya that would allow for spontaneous departure if necessary. Because of the slump in the real estate market due to the political situation and because of increasingly unfavourable exchange rates, they had to keep the apartment, at least for the time being. The couple stressed that they felt at home there and that the situation in Turkey seemed to be stabilizing. When asked whether they were planning to stay or return, they stated that they had agreed to leave that question open and that they wanted to keep their life "light," unburdened by the numerous things they would have to move from one place to another. This was Jutta and Dieter's way of saying that they were making the choice not to make a choice and that the flexibility of their lifestyle would allow them to respond to future opportunities and challenges.

Similarly, in our conversations in 2013, I asked Christa whether she was planning to stay or return to Germany at some point, and she replied that she would stay:

(...) that is, as long as I am healthy enough and the political situation is bearable (...). Of course, I have my place in Germany that I won't give up.

\section{M: So you have an apartment or an address?}

I have a small apartment. (...) And then, it is like, the apartment is really nicely furnished, and if I really wanted to go back, if I even wanted to or had to, I would not have an apartment, and finding something quickly and buying furniture and everything else that is necessary ... All my friends said, "Keep the apartment." That'll always be my refuge.

Later, in 2018, Christa, now age 83, was still living in Alanya and is keeping her apartment in Germany, where she goes three times a year for about a week each time. She stated that she would leave her Turkish home only if her health deteriorated to a point where she could no longer live her independent life. Although not particularly happy with the recent developments in Turkish politics, she emphasized that it barely affects her as a foreigner. When asked about her German refuge during our earlier conversation in 2013, her reply was similar to that of many others: "You never know what will happen."

The Germans in Alanya believed that their lives as local foreign residents will remain unaffected by political changes and turmoil. To different degrees, they also expressed concern that this might change, and some responded more actively to this insecurity by working toward an option to return to Germany. However, only one of the interviewees explicitly related her secure position of being able to leave anytime to her citizenship. Brigitte and her husband had sold their apartment and the car they owned in Germany. Unlike most of my other respondents they had given up their formal address and had relocated to Alanya to build a new life in the sun. They keep in touch with only a few friends in Germany whom they visit every 2 or 3 years, if at all. Brigitte has little interest in German affairs, speaks 
rather unfavourably of the country, politicians, work life, and social relations in general, and does not vote. However, when I asked her in 2013 about her citizenship and whether she would ever consider taking up Turkish citizenship - in which case she would probably have to renounce her German citizenship - Brigitte stated that she would never do so because "if a civil war breaks out here, we [would] be flown out."

Brigitte's statements, like those of many others, reflect a certain perception of insecurity in Turkey. However, she was the only respondent to explicitly mention the benefits of their citizenship. Although she no longer has a home or official address in Germany, she regards her German citizenship as a form of insurance that she would be rescued in the event of an outbreak of violence. Similarly, scholars have identified the strategic value of a (Western) passport as an "insurance policy" for individuals who see their home states as less secure, including Turkish citizens, because such passports allow admission to a safe country (Balta \& Altan-Olcay, 2016; Harpaz, 2013; Jeffery \& Murison, 2011). In contrast, German lifestyle migrants' social practices are not strategically planned but rather emerge in response to changing opportunities, constraints, and insecurities. Importantly, these responses do not follow instrumental strategies but result from the emigrants' "natural" options. Thus, for the majority of my interviewees, having a refuge reflects their natural confidence in the return option, one that is legally premised on formal citizenship but not explicitly mentioned in their conversations. Rather than being strategically planned, it is the unnamed spatial right, a privilege to return to a safe country that paradoxically allows them to stay abroad.

\section{Conclusion}

The Germans' local residence and sense of belonging in Alanya are made possible by their emigrant citizenship and its interconnectedness with immigrant and local laws and institutions. Together, the entangled sites of citizenship shape a specific experience of local belonging associated with foreignness as a particularly privileged condition that in times of crisis will shield them from insecurity and allow them to "seek refuge" in Germany. Although premised on the right of citizens to return to their country of origin, this right is left unspoken. However, they do not necessarily choose the option to return. Rather paradoxically, this option serves as an "insurance policy" and allows them to stay abroad. Thus, privilege can serve as a key to understanding global and local inequalities in that it brings aspects to the fore that are often "masked" (Twine \& Gardener, 2013b). A focus on privileged migration also sheds light on the return option as a neglected aspect in the study of emigrant citizenship.

German and other (usually northern) European lifestyle migrants who move to the southern coasts constitute a small segment of the current movements across the Mediterranean region. Many other migrants are moving in the opposite direction to seek protection or economic opportunities. Scholarship on these categories of immigrants has drawn attention to the "spatial rights" to enter and remain in a country as the most basic rights of citizenship (Yuval-Davis, 1991). Turkish immigrants in Germany have acquired formal citizenship in order to secure residential security and equal rights over the course of their settlement, which involves different senses of belonging (Ehrkamp \& Leitner, 2003). Similarly, recent empirical studies suggest that seeking security is one of the main reasons for acquiring citizenship for people in European countries that are severely hit by economic and financial crises (Graeber, 2016). However, the association of citizenship with 
settlement is being contested by research that theorizes "strategic citizenship" (Finotelli et al., 2018; Harpaz \& Mateos, 2019; Ong, 1999). Scholars have shown how naturalized European citizens draw on their free-movement rights to move on to other European countries (Ahrens et al., 2016). In so doing, they join individuals who take advantage of the extension of dual citizenship without (permanent) residence, drawing on ancestry, business investments, or temporary stays in their endeavor to access free travel and mobility. The "strategic citizenship" argument posits a deterritorialized value of citizenship that is specific to European and other privileged (Western) passports (Harpaz \& Mateos, 2019). Such deterritorialized value exists for individuals who were born into the uncontested status of a privileged citizen. Rather than being acquired strategically, this privilege is a naturalized experience and practice that goes along with, and in fact facilitates, local belonging and staying on abroad, not least through the option of a safe return.

Acknowledgements

not applicable.

Author's contributions

Single-authored. The author read and approved the final manuscript.

Author's information

Not applicable.

Funding

Field research for this paper was supported by grants from the Faculty of Sociology, Bielefeld University.

Availability of data and materials

The data used for this manuscript is subject to privacy regulations and not available to the public. Data is handeled and archived according to the ethical guidelines of Bielefeld University.

\section{Competing interests}

The author declares that she has no competing interests.

Received: 21 December 2018 Accepted: 16 September 2019

Published online: 13 February 2020

References

Ahmed, A. (2015). Retiring to Spain. Women's narratives of belonging and community. Bristol: Policy Press. https://doi.org/10. 2307/j.ctt1t896fb.

Ahrens, J., Kelly, M., \& van Liempt, I. (2016). Free movement?: The onward migration of EU citizens born in Somalia, Iran, and Nigeria. Population, Space and Place, 22(1), 84-98. https://doi.org/10.1002/psp.1869.

Amit, V. (Ed.) (2007). Going first class?: New approaches to privileged travel and movement. Oxford, New York: Berghahn Books.

Anthias, F. (2012). Hierarchies of social location, class and intersectionality: Towards a translocational frame. International Sociology, 28(1), 121-138. https://doi.org/10.1177/0268580912463155.

Antonsich, M. (2010). In search of belonging: An analytical framework. Geography Compass, 4(6), 644-659. https://doi.org/10. 1111/j.1749-8198.2009.00317.x.

Appadurai, A. (1998). Modernity at large: Cultural dimensions of globalization, (4th ed., ). Minneapolis: University of Minnesota Press.

Bahar, H. I., Laçiner, S., Bal, I., \& Özcan, M. (2009). Older migrants to the Mediterranean: The Turkish example. Population, Space and Place, 15(2), 509-522. https://doi.org/10.1002/psp.528.

Balkır, C., \& Kırkulak, B. (2009). Turkey, the new destination for international retirement migration. In H. Fassmann, \& D. Lane (Eds.), Migration and mobility in Europe: Trends, patterns and control, (pp. 123-143). Cheltenham: Edward Elgar.

Balkır, C., \& Südaș, I. (2014). Guests and hosts: European retirees in coastal. Turkey: Insight Turkey, 16(4), 123-142.

Balta, E., \& Altan-Olcay, Ö. (2016). Strategic citizens of America: Transnational inequalities and transformation of citizenship. Ethnic \& Racial Studies, 39(6), 939-957.

Bauböck, R. (2018). Debating transformations of National Citizenship. Cham: Springer. https://doi.org/10.1007/978-3-319-92719-0.

Benson, M. (2013). Postcoloniality and privilege in new lifestyle flows: The case of north Americans in Panama. Mobilities, 8(3), 313-330. https://doi.org/10.1080/17450101.2013.810403.

Benson, M. (2016). Deconstructing belonging in lifestyle migration: Tracking the emotional negotiations of the British in rural France. European Journal of Cultural Studies, 19(5), 481-494. https://doi.org/10.1177/1367549416631554.

Benson, M., \& O'Reilly, K. (Eds.) (2009a). Lifestyle migration: Expectations, aspirations and experiences. Farnham: Ashgate.

Benson, M., \& O'Reilly, K. (2009b). Migration and the search for a better way of life: A critical exploration of lifestyle migration. The Sociological Review, 57(4), 608-625. https://doi.org/10.1111/j.1467-954X.2009.01864.x.

Benson, M., \& O'Reilly, K. (2018). Lifestyle migration and colonial traces in Malaysia and Panama. London: Palgrave Macmillan.

Bosniak, L. (2006). The citizen and the alien. Princeton and Oxford: Princeton University Press. 
Castles, S. (2005). Nation and empire: Hierarchies of citizenship in the new global order. International Politics, 42(2), 203-224. https://doi.org/10.1057/palgrave.ip.8800107.

Coldron, K., \& Ackers, L. (2007). (Ab) using European citizenship? EU retired migrants and the exercise of healthcare rights. Maastricht Journal of European and Comparative Law, 14(3), 287-302.

Croucher, S. (2009). The other side of the fence: American migrants in Mexico. Austin T.X: University of Texas Press.

Domradio (2016). Katholischer Auslandsseelsorger zur Situation in der Türkei "Können Glauben ohne Hindernisse ausüben. [Catholic expatriate priest on the situation in Turkey "They can follow their beliefs without obstacles"]. Retrieved from https://www.domradio.de/themen/weltkirche/2016-11-17/katholischer-auslandsseelsorger-zur-situation-der-tuerkei. Accessed 1 July 2019.

Desforges, L., Jones, R., \& Woods, M. (2005). New geographies of citizenship. Citizenship Studies, 9(5), 439-451. https://doi.org/ 10.1080/13621020500301213

Deutsche Welle (2016). Deutsche in der Türkei zwischen Trotz und Angst [Germans in Turkey between Defiance and Fear]. Retrieved from http://www.dw.com/de/deutsche-in-der-türkei-zwischen-trotz-und-angst/a-36610221. Accessed 7 Jan 2019.

Ehrkamp, P., \& Leitner, H. (2003). Beyond national citizenship: Turkish immigrants and the (re) construction of citizenship in Germany. Urban Geography, 24(2), 127-146. https://doi.org/10.2747/0272-3638.24.2.127.

Faist, T. (2001). Social citizenship in the European Union: Nested membership. Journal of Common Market Studies, 39(1), 37-58. https://oi.org/10.1111/1468-5965.00275.

Faist, T., Fauser, M., \& Reisenauer, E. (2013). Transnational migration. Cambridge (UK) and Malden (USA): Polity Press.

Fauser, M. (2020) Mobile citizenship. Spatial privilege and the transnational lifestyles of senior citizens. London: Routledge.

Ferbrache, F., \& Yarwood, R. (2015). Britons abroad or European citizens? The negotiation of (trans) national space and citizenship by British migrants in France. Geoforum, 62, 73-83. https://doi.org/10.1016/j.geoforum.2015.03.021.

Finotelli, C., La Barbera, M., \& Echeverría, G. (2018). Beyond instrumental citizenship: The Spanish and Italian citizenship regimes in times of crisis. Journal of Ethnic \& Migration Studies, 44(14), 2320-2339. https://doi.org/10.1080/1369183X.2017. 1345838.

Graeber, J. (2016). Citizenship in the shadow of the euro crisis: Explaining changing patterns in naturalisation among intra-EU migrants. Journal of Ethnic \& Migration Studies, 42(10), 1670-1692. https://doi.org/10.1080/1369183X.2016.1162353.

Green, P. (2014). Mobility regimes in practice: Later-life westerners and visa runs in South-East Asia. Mobilities, 10(5), 748-763. https://doi.org/10.1080/17450101.2014.927203.

Guarnizo, L. E., \& Smith, M. P. (1999). The locations of transnationalism. In M. P. Smith, \& L. E. Guarnizo (Eds.), Transnationalism from below, (pp. 3-34). New Brunswick: Transaction Publishers.

Gustafson, P. (2001). Retirement migration and transnational lifestyles. Ageing and Society, 21(4), 371-394. https://doi.org/10. 1017/S0144686X01008327.

Hardill, I., Spradberry, J., Arnold-Boakes, J., \& Marrugat, M. L. (2005). Severe health and social care issues among British migrants who retire to Spain. Ageing and Society, 5(25), 769-783. https://doi.org/10.1017/S0144686X05004034.

Harpaz, Y. (2013). Rooted cosmopolitans: Israelis with a European passport - History, property, identity. International Migration Review, 47(1), 166-206. https://doi.org/10.1111/imre.12017.

Harpaz, Y., \& Mateos, P. (2019). Strategic citizenship: Negotiating membership in the age of dual nationality. Journal of Ethnic and Migration Studies, 45(6), 843-857. https://doi.org/10.1080/1369183X.2018.1440482.

Hayes, M. (2015). It is hard being the different one all the time: Gringos and racialized identity in lifestyle migration to Ecuador. Journal of Ethnic \& Migration Studies, 38(6), 943-958. https://doi.org/10.1080/01419870.2014.943778.

Huber, A., \& O'Reilly, K. (2004). The construction of Heimat under conditions of individualised modernity: Swiss and British elderly migrants in Spain. Ageing and Society, 24(3), 327-351. https://doi.org/10.1017/S0144686X03001478.

İçduygu, A., \& Sert, D. (2009). Country profile Turkey. focus Migration, 5. http://focus-migration.hwwi.de/Turkey-Update-04-20.6 026.0.html?\&L=1.

Isin, E. (2008). Theorizing acts of citizenship. In E. Isin, \& G. M. Nielsen (Eds.), Acts of citizenship, (pp. 15-43). London: Zed Books.

Janoschka, M., \& Haas, H. (2014). Contested spatialities of lifestyle migration: Approaches and research questions. In M. Janoschka \& H. Haas (Eds.), Contested Spatialities, lifestyle migration and residential tourism (pp. 1-12). London and New York: Routledge.

Jeffery, L., \& Murison, J. (2011). The temporal, social, spatial, and legal dimensions of return and onward migration. Population, Space and Place, 17(2), 131-139. https://doi.org/10.1002/psp.606.

Kaiser, C. (2011). Transnationale Altersmigration in Europa: Sozialgeografische und gerontologische Perspektiven. [Transnational migration of the elderly in Europe. Socialgeographical and gerontological perspectives]. Wiesbaden: VS Verlag für Sozialwissenschaften.

King, R. (2000). Southern Europe in the changing global map of migration. In R. King, G. Lazaridis, \& C. G. Tsardanidēs (Eds.), Eldorado or fortress? Migration in southern Europe, (pp. 3-26). Basingstoke: Macmillan Press.

King, R., Warnes, A. M., \& Williams, A. M. (2000). Sunset lives: British retirement migration to the Mediterranean. Oxford: Berg.

Kofman, E. (1995). Citizenship for some but not for others: Spaces of citizenship in contemporary Europe. Political Geography, 14(2), 121-137. https://doi.org/10.1016/0962-6298(95)91660-V.

Kordel, S., \& Weidinger, T. (2019). Onward (im)mobilities: Conceptual reflections and empirical findings from lifestyle migration research and refugee studies. Die Erde, 150(1), 1-16. https://doi.org/10.12854/erde-2019-408.

Leitner, H., \& Ehrkamp, P. (2006). Transnationalism and migrants' imaginings of citizenship. Environment and Planning A, 38(9), 1615-1632. https://doi.org/10.1068/a37409.

Leuchter, N. (2014). Creating other options: Negotiationg the meanings of citizenships. Citizenship Studies, 18, 776-790. https://doi.org/10.1080/13621025.2014.944780

Levitt, P., \& Glick Schiller, N. (2004). Conceptualizing simultaneity: A transnational social field perspective on society. International Migration Review, 38(3), 1002-1039. https://doi.org/10.1111/j.1747-7379.2004.tb00227.x.

Lundström, C. (2014). White migrations. In Gender, whiteness and privilege in transnational migration. Basingstoke: Palgrave Macmillan. 
McIntosh, P. (2010 [1989]). White privilege: Unpacking the invisible knapsack. Freedom and Peace, 8-10 Retrieved from www. nationalseedproject.org.

McWatters, M. R. (2009). Residential tourism: (De)constructing paradise. Bristol: Channel view publications.

Nudrali, Ö., \& O'Reilly, K. (2009). Taking the risk: The British in Didim, Turkey. In M. Benson, \& K. O'Reilly (Eds.), Lifestyle migration: Expectations, aspirations and experiences, (pp. 126-152). Farnham: Ashgate.

Ong, A. (1999). Flexible citizenship. The cultural logics of Transnationality. Durham and London: Duke University Press.

Rodríguez, V., Fernández-Mayoralas, G., \& Rojo, F. (1998). European retirees on the Costa del Sol: A cross- national comparison. International Journal of Population Geography, 4(2), 183-200. https://doi.org/10.1002/(SICI)1099-1220(199806)4:2<183::AIDIJPG101>3.0.CO;2-8.

Staeheli, L. A. (2003). Introduction: Cities and citizenship. Urban Geography, 24(2), 97-102. https://doi.org/10.2747/0272-3638. 24.2.97.

Staeheli, L. A., Ehrkamp, P., Leitner, H., \& Nagel, C. R. (2012). Dreaming the ordinary: Daily life and the complex geographies of citizenship. Progress in Human Geography, 36(5), 628-644. https://doi.org/10.1177/0309132511435001.

Südaş, l., \& Mutluer, M. (2006). Immigration européenne de retraités vers la "Riviera turque": le cas d'Alanya (côte méditerranéenne). Revue Européenne des Migrations Internationales, 22(3), 1-18. https://doi.org/10.4000/remi.3381.

Twine, F. W., \& Gardener, B. (2013a). Geographies of privilege. London and New York: Routledge.

Twine, F. W., \& Gardener, B. (2013b). Introduction. In F. W. Twine, \& B. Gardener (Eds.), Geographies of privilege, (pp. 1-16). London and New York: Routledge.

Unutulmaz, K. O. (2006). The unprepared host: Governance of unexpected "multiculturalism" in Turkey. In Koc University, Istanbul: Paper presented at third annual graduate student conference titled: Borders and Mobilities: Rethinking migration. European-Integration and: Prospects.

Van Noorloos, F. (2013). Residential tourism and multiple mobilities: Local citizenship and community fragmentation in Costa Rica. Sustainability, 5(2), 570-589. https://doi.org/10.3390/su5020570.

Yuval-Davis, N. (1991). The citizenship debate: Women, ethnic processes and the state. Feminist Review, (39), 58-68. https:// doi.org/10.2307/1395439.

ZDF (2016). Deutsche Auswanderer in Türkei [German expatriates in Turkey]. Retrieved from https://www.zdf.de/nachrichten/ heute-in-europa/videos/auswanderer-in-der-tuerkei-100.html

\section{Publisher's Note}

Springer Nature remains neutral with regard to jurisdictional claims in published maps and institutional affiliations.

\section{Submit your manuscript to a SpringerOpen ${ }^{\circ}$ journal and benefit from:}

- Convenient online submission

- Rigorous peer review

- Open access: articles freely available online

- High visibility within the field

Retaining the copyright to your article

Submit your next manuscript at $\boldsymbol{\nabla}$ springeropen.com 